\title{
The Mediating Role of Self-Sufficiency in the Relationship Between Coronavirus Anxiety and Suicide Probability
}

Koronavirüs Anksiyetesiyle İntihar Olasılığı Arasındaki İlişkide Öz Yeterliliğin Aracı Rolü

\section{Musa YILDIRIM [1] Ümit BAYIN[2] Özge AKINCI GÖKDAL[3] Mustafa KOÇ[4]}

$\mathrm{Bu}$ araştırmanın amacı Covid-19 pandemisinde üniversite öğrencilerinin koronavirüs anksiyetesi ile intihar olasılığı arasındaki ilişkide öz yeterliliğin aracı rolünü incelemektir. Araştırmaya 341 üniversite öğrencisi katılım göstermiștir. Katılımcılardan veri toplamak için Kişisel Bilgi Formu, İntihar Olasılığı Ölçeği, Koronavirüs Anksiyetesi Ölçeği ve Genel Öz Yeterlilik Ölçeği kullanılmıştır. Elde edilen veriler SPSS 26.0 paket programında analiz edilmiştir. Veriler incelenirken Bağımsız Örneklemler için t Testi, Pearson Momentler Çarpımı Korelasyon Analizi ve Hiyerarşik Regresyon Analizi kullanılmıștır. Aynı zamanda aracı değişkenin bağımlı değişkenle bağımsız değişken arasındaki aracı rolünü incelemek amacıyla yenide örnekleme yönteminden (bootstrapping) faydalanılmıştır. Elde edilen bulgulara göre öz yeterliliğin koronavirüs anksiyetesi ve intihar olasılığı arasındaki ilişkide kısmi olarak aracı rol oynadığı bulunmuştur. Aynı zamanda koronavirüs sebebiyle yalnız kaldığını söyleyenlerin koronavirüs kaygısı puanlarının yalnız kalmadığını söyleyenlere göre daha yüksek olduğu bulunmuştur. Son olarak pandemi sürecinde, pandemi şartlarından dolayı istismara uğrayanların koronavirüs kaygısı ve intihar olasılıkları puanlarının istismara uğramayanlara göre daha yüksek olduğu belirlenmiştir. Araştırmadan elde edilen sonuçlara göre öz yeterliliğin koronavirüs anksiyetesi ve intihar olasıllğı arasındaki ilişkiye kısmi olarak aracılık ettiği bulunmuştur. Buna göre öz yeterliliğin artmasıyla intihar olasılığının azaldığı belirlenmiştir. Bulgular alanyazın ışı̆̆ında tartışılmıştır.

Anahtar Kelimeler: koronavirüs anksiyetesi, intihar olasılığı, öz yeterlilik, pandemi, üniversite öğrencileri

Received Date:23 September 2021

The aim of this study is to examine the mediating role of self-efficacy in the relationship between coronavirus anxiety and suicide probability of university students during the Covid-19 pandemic. 341 university students participated in the study. While analyzing the data, Unpaired t Test, Pearson Product Moment Correlation Analysis and Hierarchical Regression Analysis were used. At the same time, the bootstrapping method was used to examine the role of mediating variable between the dependent variable and independent variable. According to the findings, it was found that self-efficacy plays a partial mediating role in the relationship between coronavirus anxiety and the suicide probability. In addition, it was also found that those who said they became lonely because of coronavirus had higher coronavirus anxiety scores than those who said they were not alone. Finally, it was determined that during the pandemic process, the coronavirus anxiety and suicide probability scores of those who were abused due to pandemic conditions were higher than those who were not. According to results obtained from the study, self-efficacy was found to partially mediate the relationship between coronavirus anxiety and the suicide probability. Accordingly, it was determined that the probability of suicide decreased with increased self-efficacy.

Key Words: coronavirus anxiety, suicide probability, self-efficacy, pandemic, university students

Yıldırım, M., Bayın, Ü., Akıncı Gökdal, Ö., \& Koç, M. (2021). The mediating role of self-sufficiency in the relationship between coronavirus anxiety and suicide probability. Humanistic Perspective, 3 (3), 696-719.

https://doi.org/10.47793/hp.998182

\footnotetext{
[1] PhD Student | Yildiz Technical University | Guidance and Psychological Counseling | Istanbul | Turkey | ORCID: 0000-0003-2051-6699| musayildirim78@gmail.com

[2] PhD Student | Duzce University | Faculty of Education| Duzce | Turkey | ORCID: 0000-0001-6238-7579

[3] PhD Student | Duzce University | Faculty of Education | Duzce | Turkey | ORCID: 0000-0002-7597-661X

[4] Prof. Dr. | Duzce University | Faculty of Education | Duzce | Turkey | ORCID: 0000-0002-8644-4109
} 


\section{INTRODUCTION}

he world is still facing coronavirus, which originated on December 31, 2019 in Wuhan, China, and which is highly threatening the health of individuals. It has been stated that coronavirus can be easily transmitted from person to person and cause severe diseases and death (T.C. Ministry of Health Covid-19 Guidelines, 2020). The spread of coronavirus to a wide area including Asia, Europe, Australia, North and South America and Africa in a short period of time has led the World Health Organization (who) to declare this virus a pandemic (WHO, 2020). With the declaration of the pandemic, the states began to implement a number of measures to deal with coronavirus, taking into account hygiene rules and the distance of transmission between humans.

The world is trying to control the coronavirus. But there is no exact date for how long the pandemic will last and how long it will disrupt our lives. The continuation of the risk threatens the physical health of individuals as well as has a significant impact on their psychological health. Depression, anxiety, sleep disorders, mania, obsessive compulsive disorder (OCD), posttraumatic stress disorder (PTSD), panic disorder, generalized anxiety disorder and hyperactivity are stated to be the most common psychiatric disorders during and after pandemics (Cheyette \& Cummings, 1995; Huang \& Zhao, 2020; Mak, Chu, Pan, Yiu \& Chan, 2009). In addition, the concept of coronavirus anxiety has been put forward to describe anxiety about being infected with coronavirus. Coronavirus anxiety describes the emotional (fear, anxiety, anger), cognitive (repetitive thoughts, prejudices, etc.), behavioral (avoidance behaviors, dysfunctional behaviors, etc.) and physical (sleep disturbances, crying, etc.) symptoms related to coronavirus (Lee, 2020). Studies conducted during the coronavirus pandemic found that coronavirus anxiety was closely related to death anxiety and depression (Lee et al., 2020).

Unpredictable consequences, uncertainties, restrictive practices such as social isolation and quarantine cause anxiety, sadness, fear, panic, resentment, anger, frustration, guilt, despair and loneliness in individuals (Sher, 2020). Prolongation of the quarantine process, anxiety about infection of the individual himself/herself or one of his / her family members, inability to obtain actual information from the authorities involved in the process and inadequacies in medical care increase the negative psychological impact on individuals (Courtet et al., 2020; Ammerman et al., 2020). Such symptoms, which are common for many individuals to experience in a crisis situation, can lead to serious mental problems and suicidal behavior (Banerjee, 2020). In the study of Lai et al. (2020) with healthcare workers and patients infected with coronavirus in China, it was found that the pandemic was associated with anxiety, depression, distress, sleep disorders and suicidal tendency. Similarly, Lee et al (2020) also found significant changes in the social attitudes of individuals experiencing coronavirus anxiety in their study on adults in the 
United States. In addition, there are studies that indicate an increase in the likelihood of suicide when coronavirus is transmitted and afterwards (Dunmore, 2020, Reger, Stanley and Joiner, 2020, Sahoo et al., 2020). Therefore, the coronavirus and the measures taken to deal with coronavirus have some negative psychological consequences.

Mann et al. (2005) emphasized in their study that individuals with pre-existing psychiatric disorders such as psychotic and substance use disorders were at high risk of suicide. It was found that women, minority groups, people with socioeconomic disadvantages, those unemployed, handicapped and those with chronic physical or psychological diseases had a higher risk of suicide during the pandemic (Iob, Steptoe \& Fancourt, 2020). Besides, job loss and economic crisis are other well-known risk factors for suicide (Huang \& Zhao, 2020). Historically, economic crises have been reported to be associated with high suicide rates (Tull et al., 2020; Oyesanya, Lopez-Morinigo \& Dutta; 2015). In this context, it is emphasized that the unemployment resulting from the pandemic and the economic crisis may be associated with higher suicide rates in the future (Van Orden et al., 2010). Therefore, in addition to the psychological difficulties of the pandemic process, social changes also affect people negatively.

Durkheim emphasized that egoistic suicide occurs when an individual is not sufficiently included in a particular group, in other words, has a limited number of social ties (Berk, 2006). It has also been stated in leading suicide theories that strong social bonding plays a key role in preventing suicide (Huang \& Zhao, 2020). The fact that a person's social bonds are strong and has a sense of belonging will lead to greater efforts to fulfill their responsibilities against themselves and their environment, as well as an increase in self-efficacy. Self-efficacy is defined as the motivation and belief that an individual develops that he or she has the necessary ability to perform an action and that he or she can perform an action (Bandura,1999). According to Alabay (2006), self-efficacy means that individuals believe in themselves in order to successfully overcome negative events that they have gone through. Senemoglu (2012), on the other hand, defined self-efficacy as the self-judgment of a person in order to fulfill the desired performance. In short, self-efficacy can be expressed as an individual's self-belief in performing a certain activity.

The level of self-efficacy varies from individual to individual. But self-efficacy is a skill that can be improved (Craft, 2002; Gilliam, 2005). Individuals who have strong self-efficacy in certain areas can take more responsibility and plan for higher goals (Mercer, 2004). According to Bandura, a high level of self-efficacy perception positively affects individuals' personal wellbeing, psychological adaptation processes, ability to manage a stressful situation, self-values and social relationships (Bury, 2007). Supporting this view, Tate (2005) states that individuals with high self-efficacy are more persistent in maintaining their commitment to their goals, prefer to 
face rather than escape from a threatening situation, and struggle decisively to achieve success. However, it is reported that individuals who have doubts about their self-efficacy perceive complex processes as threats and prefer to avoid these threats, can attribute the possible failures in difficult situations to themselves, and will focus on negative processes instead of focusing on solutions (Taylor \& Bury, 2007). In addition, individuals those who perceive their self-efficacy as low experience more tension and stress than individuals with high self-efficacy (Keskin \& Orgun, 2006). Therefore, people with high levels of self-efficacy have a higher capacity to cope with difficulties. As a matter of fact, self-efficacy is seen as a protective factor against suicide (Liu, et al, 2020).

As a result, risk factors for mental health increased during the coronavirus pandemic. Along with the risk factors that occur during the pandemic, it is predicted that the phenomenon of suicide, a mental health problem, may also increase (Brown \& Schuman, 2020). But it is reported that the belief in self-efficacy, which is seen as a structure that will help to deal with the crises encountered in a healthy way, can reduce the likelihood of suicide. Based on this, this study aims to examine the mediating role of self-efficacy in the relationship between coronavirus anxiety and the suicide probability.

\section{Importance}

In times of pandemic, people are faced with many uncertainties. They have to take various measures to prevent the disease. Both the disease itself and the measures taken to protect it adversely affect the mental health of the community (Courtet et al., 2020; Ammerman et al., 2020). Researches have shown that the probability of suicide in individuals increases during pandemic periods (Iob, Steptoe and Fancourt, 2020). Therefore, this research is seen as an important research to determine how the self-efficacy skills of individuals affect the probability of suicide. It is hoped that the findings obtained from this study will be a source for intervention studies to be carried out for community mental health during pandemic periods.

\section{Purpose}

In this study, it was aimed to examine the mediating role of self-efficacy in the relationship between university students' coronavirus anxiety and suicide probability. In addition to this main purpose, the following research questions were examined.

1. Is there a significant difference in the probability of suicide, coronavirus anxiety and self-efficacy scores of university students according to gender?

2. Is there a significant difference in suicide probability, coronavirus anxiety and selfefficacy scores of university students according to whether or not they are alone during the pandemic process? 
3. Is there a significant difference in suicide probability, coronavirus anxiety and selfefficacy scores of university students according to the situation of being abused during the pandemic process?

\section{METHOD}

In this section, information is given about the research model used in the study, study group and data collection, data collection tools, data analysis and ethics approval.

\section{Research Model}

In this study, it was aimed to examine the mediating role of self-efficacy in the relationship between coronavirus anxiety and suicide probability of university students. The research was conducted using a descriptive-type relational screening model. In this context, coronavirus anxiety is treated as an independent variable, self-efficacy is treated as a mediating variable and suicide probability is treated as a dependent variable. According to the assumption of the model used in the study, the relationship between variables will be tested in two models. In the first model, the predictor role of the independent variable on the dependent variable will be examined. If the independent variable predicts the dependent variable, the second model will be created. In the second model, the predictor role of the mediating variable and the independent variable on the dependent variable will be determined. In the second model, if the predictor effect of the independent variable on the dependent variable decreases compared to the first variable, it can be said that the mediating variable has a partial mediating effect on this relationship. Another possibility is that in the second model, the predictor effect of the independent variable on the dependent variable is completely absent. In this case, it can be said that the mediating variable fully mediates the relationship between the dependent variable and the independent variable (Preacher \& Hayes, 2004).

\section{Study Group and Data Collection}

A total of 341 (247 Females, 94 Males) university students participated in the study. The average age of the students was 20.3. The age range was between 17-41. Considering the distribution of university students on the basis of faculties, it is observed that 94 students from the Faculty of Education, 17 from the Faculty of Arts and Sciences, 65 from the Faculty of Engineering, 49 from the Faculty of Medicine, 18 from the Faculty of Theology, 16 from the Faculty of Economics and Administrative Sciences, 22 from the Faculty of Health Sciences, 40 from the Faculty of Health Sciences and 20 from the Faculty of Law participated in the study. 


\section{Data Collection Tools}

Personal Information Form, Suicide Probability Scale, Coronavirus Anxiety Scale and General Self-efficacy Scale were used to collect data from the participants in the study.

Suicide Probability Scale. The Suicide Probability Scale was developed by Cull \& Gill (1990) to measure risks devoted to suicide. Scale was adapted into Turkish by Atll, Eskin \& Dereboy (2009). In the study, which examined the psychometric properties of the scale, it was observed that 36 items were divided into 4 factors. It has been stated that these four factors can be considered together and a transaction can be made with the total scores taken from the scale. Again, in the same study, it was found that the number of internal consistency coefficient of the scale is above .80 . In the current research, the internal consistency coefficient was determined as .90 .

Coronavirus Anxiety Scale. The Coronavirus Anxiety Scale was developed by Lee (2020) to measure the anxiety arising from coronavirus. The scale was adapted into Turkish by Evren et al (2020). The scale consists of 5 items aimed at measuring anxiety. These 5 items revealed a one-factor structure. When the psychometric properties of the scale are examined, the internal consistency coefficient was found as .80, while in the current study it has been calculated as 83 .

General Self-Efficacy Scale. It was developed by Schwarzer \& Jerusalem (1995) for the purpose of measuring the self-efficacy belief that arises when people deal with stressful and challenging situations. The scale was adapted into Turkish by Aypay (2010). The 10 items found on the scale are divided into two factors. When all items found on the scale were evaluated together, the internal consistency coefficient was found to be 83. In the current study, the internal consistency coefficient was calculated as 91.

\section{Data Collection Process}

This study was conducted with university students. The data used in the study were collected via Google Forms obtained from the students who were studying at Sakarya University and Düzce University in the Academic Year 2020-2021.

\section{Analysis of Data}

SPSS 26.0 package program was used to analyze the data. The analysis part of the study consists of two stages. In the first step, whether the data set is suitable for regression analysis was examined. For this, kurtosis and skewness values of coronavirus anxiety, suicide probability and self-efficacy scores were considered (Mertler \& Vannatta, 2005). Kurtosis and skewness values were found to be between \pm 1.5 for all three variables. Then it was checked whether there are multiple connections between variables. As seen in Table 2, it has been understood that there is no multiple connection between the variables. Thus, it was determined that the data set 
was suitable for regression analysis (Tabachnick \& Fidell, 2013). Hierarchical regression analysis was used to determine the predictive role of coronavirus anxiety and self-efficacy on suicide probability. At the same time, a 10,000 replicate bootstrapping method was used to examine the mediating role of self-efficacy between coronavirus anxiety and suicide probability. SPSS-macro program (Preacher \& Hayes, 2004; 2008) was used for this analysis.

\section{Ethical Approval}

The research was carried out with the approval of Düzce University Scientific Research and Ethics Committee dated 06.01.2021 and numbered E-78187535-300-647.

\section{RESULTS}

In this part of the study, the results obtained from the analysis were presented. Table 1 contains unpaired t-test results with regard to examination of the variables in terms of gender as well as whether being abused and whether being alone in the pandemic process.

When Table 1 is examined, it is understood that the suicide probability scores of university students do not differ by gender $(t=1.40, p>0.05)$ versus coronavirus anxiety $(t=5.50$, $\mathrm{p}<0.05)$ and self-efficacy $(\mathrm{t}=-3.10, \mathrm{p}<0.05)$ scores differ by gender. Accordingly, it was found that women's coronavirus anxiety scores were significantly higher than men's and men's selfefficacy scores were significantly higher than women's.

\section{Table 1}

T-test results with regard to examination of the variables in terms of gender as well as whether being abused and whether being alone in the pandemic process.

\begin{tabular}{|c|c|c|c|c|c|c|c|}
\hline \multirow{2}{*}{ Variables } & \multirow{2}{*}{ Groups } & \multirow{2}{*}{$\mathbf{N}$} & \multirow{2}{*}{$\overline{\mathbf{x}}$} & \multirow{2}{*}{ Ss } & \multicolumn{3}{|c|}{ Test } \\
\hline & & & & & $t$ & Sd & $p$ \\
\hline \multirow{2}{*}{ Suicide Probability } & Female & 247 & 40.23 & 17.58 & \multirow{2}{*}{1.40} & \multirow{2}{*}{339} & \multirow{2}{*}{0.118} \\
\hline & Male & 94 & 37.39 & 13.79 & & & \\
\hline \multirow{2}{*}{ Coronavirus Anxiety } & Female & 247 & 3.75 & 3.92 & \multirow{2}{*}{5.50} & \multirow{2}{*}{339} & \multirow{2}{*}{0.000} \\
\hline & Male & 94 & 1,40 & 2.00 & & & \\
\hline \multirow{2}{*}{ Self- Efficacy } & Female & 247 & 28.55 & 6.10 & \multirow{2}{*}{-3.10} & \multirow{2}{*}{339} & \multirow{2}{*}{0.002} \\
\hline & Male & 94 & 30.69 & 5.41 & & & \\
\hline \multirow{2}{*}{ Suicide Probability } & Alone & 172 & 41.17 & 15.37 & \multirow{2}{*}{1.93} & \multirow{2}{*}{339} & \multirow{2}{*}{0.053} \\
\hline & Not Alone & 169 & 37.69 & 17.29 & & & \\
\hline \multirow{2}{*}{ Coronavirus Anxiety } & Alone & 172 & 3.63 & 3.80 & \multirow{2}{*}{2.72} & \multirow{2}{*}{339} & \multirow{2}{*}{0.007} \\
\hline & Not Alone & 169 & 2.57 & 3.41 & & & \\
\hline \multirow{2}{*}{ Self- Efficacy } & Alone & 172 & 29.57 & 5.92 & \multirow{2}{*}{1.34} & \multirow{2}{*}{339} & \multirow{2}{*}{0.182} \\
\hline & Not Alone & 169 & 28.70 & 6.04 & & & \\
\hline \multirow{2}{*}{ Suicide Probability } & Abused & 30 & 50.06 & 13.77 & \multirow{2}{*}{3.72} & \multirow{2}{*}{339} & \multirow{2}{*}{0.000} \\
\hline & Not Abused & 311 & 38.42 & 16.56 & & & \\
\hline \multirow{2}{*}{ Coronavirus Anxiety } & Abused & 30 & 5.53 & 4.51 & 388 & 339 & 0000 \\
\hline & Not Abused & 311 & 2.87 & 3.47 & 3.00 & 309 & 0.000 \\
\hline Self-Efficacy & Abused & 30 & 29.06 & 5.65 & $-0,07$ & 339 & 0941 \\
\hline sell- Emcacy & Not Abused & 311 & 29.15 & 6.03 & -0.01 & 339 & 0.941 \\
\hline
\end{tabular}


Table 1 also includes the results of the study on the difference between the scores of participants who said yes and no to the judgment "I was alone for a long time due to Coronavirus". Accordingly, it was found that the suicide probability ( $t=1,91, p>0.05)$ and selfefficacy scores ( $\mathrm{t}=1.34, \mathrm{p}>0.05$ ) of university students did not differ depending on whether they were alone for a long time due to coronavirus. However, it was found that those who said they were alone due to coronavirus had higher coronavirus anxiety scores than those who said they were not alone $(t=2,72, p>0.05)$.

The latest finding in Table 1 relates to comparing the scores of participants who answered yes or no to the question "Have you been subjected to physical, emotional or sexual abuse during your stay at home to protect yourself from Coronavirus?". As a result of the T test, there was no difference in self-efficacy scores between those who said yes to this question and those who said no $(\mathrm{t}=-0.07, \mathrm{p}<0.05)$. In addition, coronavirus anxiety scores $(\mathrm{t}=-3.88, \mathrm{p}<0.05)$ and suicide probability scores $(\mathrm{t}=3.72, \mathrm{p}<0.05)$ of those who said yes to this question were higher than those who said no.

Table 2 includes the results of Pearson Product Moments Correlation Analysis with regard to the examination of the relationship between suicide probability, coronavirus anxiety and self- efficacy scores of the university students.

\section{Table 2}

Correlation analysis results related to the examination of the relationship between variables

\begin{tabular}{lccc}
\hline & Suicide Probability & Coronavirus Anxiety & Self-Efficacy \\
\hline Suicide Probability & 1 & $.307^{* *}$ & $-.296^{* *}$ \\
Coronavirus Anxiety & & 1 & $-.139^{*}$ \\
Self-Efficacy & & & 1 \\
\hline
\end{tabular}

When Table 2 is examined, it is seen that there is a relationship between suicide probability and coronavirus anxiety at a level of 0.307 , between suicide probability and selfefficacy at a level of -,296, and between coronavirus anxiety and self-efficacy at a level of -,139. Table 3 contains the results of hierarchical regression analysis for the prediction of the probability of suicide.

Table 3

Correlation analysis results on predictability of suicide

\begin{tabular}{lcccccccc}
\hline Variables & $\boldsymbol{R}^{\mathbf{2}}$ & $\boldsymbol{\Delta R}^{\mathbf{2}}$ & $\boldsymbol{B}$ & Standard Error & $\boldsymbol{\beta}$ & $\boldsymbol{t}$ & $\boldsymbol{p}$ & $\boldsymbol{F}$ \\
\hline Step 1 & .09 & & & & & & & 35.25 \\
Coronavirus Anxiety & & & -.13 & .23 & .31 & 5.93 & .000 & \\
Step 2 & .16 & .06 & & & & & & \\
Coronavirus Anxiety & & & -.12 & .23 & .27 & 5.38 & .000 & 26.26 \\
Self-Efficacy & & & .03 & .14 & -.26 & -5.12 & .000 & \\
\hline
\end{tabular}


Looking at Table 2, it is seen that hierarchical regression analysis occurs in two stages. In the first stage, coronavirus anxiety was added into the model. At this stage, it was found that coronavirus anxiety positively predicted the suicide probability at a rate of $9 \%(\mathrm{R} 2=.09)$ $(\mathrm{p}<0.01)$. In the second stage, self-efficacy was added to the model. Self-efficacy was found to make a negative $6 \%$ contribution to the model $(\Delta \mathrm{R} 2=06)$. Thus, coronavirus anxiety and selfefficacy predicts $16 \%$ of suicide probability $(\mathrm{R} 2=16)$.

In Model 2 , it was observed that the $\beta$ coefficient for coronavirus anxiety decreased from .31 to .27 as self-efficacy entered the model. This result suggests that self-efficacy may have a mediating role between coronavirus anxiety and the suicide probability. The results of the analysis carried out to examine the mediating role of self-efficacy between coronavirus anxiety and suicide probability are shown in Figure 1.

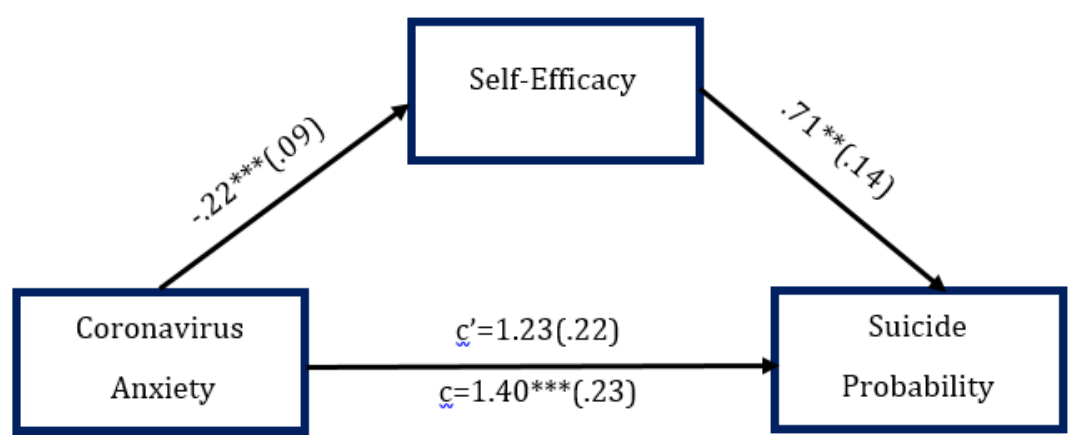

Figure 1. The mediating role of self-efficacy between coronavirus anxiety and suicide probability

All effect values in Figure 1 are non-standardized values, and the values in parentheses are standard error values. At the same time, the direct effect from coronavirus anxiety to suicide probability was expressed with the value of $c^{\prime}$, and the total effect was expressed with the value of c. Figure 1 includes the results of a 10,000-replicated bootstrapping method to examine the mediating role between coronavirus anxiety and suicide probability. As a result of the analysis, it was found that the probability of suicide does not remain in the range of zero values when being predicted. Based on this, it can be said that self-efficacy has a partial mediating role between coronavirus anxiety and the suicide probability.

\section{CONCLUSION, DISCUSSION AND RECOMMENDATIONS}

In this part of the study, the findings are discussed in the light of the relevant literature. The study found that the suicide probability scores of university students did not differ by gender. Research is available in the literature to support this finding (Kjoller \& Helweg-Larsen, 2000; Thomas, Crawford, Meltzer \& Lewis, 2002). However, there are studies which indicate 
that the suicide probability is higher in women (Atay, Eren \& Gündoğar, 2012; Molina \& Duarte, 2006; Whetstone, Morrissey \& Cummings, 2007) or higher in men (Batıgün, 2005; Harriss, Hawton \& Zahl, 2005; Kumar, Mohan, Ranjith \& Chandrasekaran, 2006; Şahin \& Batıgün, 2009). Therefore, there is no consensus on this issue. Suicide may be related to being in a risk group other than gender. As a matter of fact, it is believed that the probability of suicide is similar in both men and women because the pandemic process affects the entire society and damages their psychological health.

Another finding of the study was that women's coronavirus anxiety scores were significantly higher than men's. Similar findings have been reached in many studies (Çölgeçen \& Çölgeçen, 2020; Göksu \& Kumcağız, 2020; Erdoğdu, Koçoğlu \& Sevim, 2020; Kul, Demir \& Katmer, 2020). Although these studies make up the majority of the literature, there are also studies that express that there is no difference by gender (Zhang et al., 2020). This can be explained by social gender perception. The fact that works, responsibilities and regulations at home during the coronavirus process are more expected from women and cleaning, food and other household tasks are considered to be overcome by women, and an increase in time spent at home due to social isolation may have caused a higher level of anxiety in women.

According to another result of the study, it was found that men's self-efficacy scores were significantly higher than women. Although there are studies in the literature that show similarities with this result (Akbay \& Gizir, 2010; Akkoyunlu \& Orhan, 2003; Selvi, 2020), there are also studies that do not envisage a significant difference according to gender (Keskin, 2019). The result of the research can be explained by missions attributed to men in societies based on male dominance. It can be said that the missions assigned to the man, such as being at the forefront, successful, active and competent may cause him to develop positive attitudes and perceive a higher level of self-efficacy.

As a result of the study, it was found that suicide probability and self-efficacy scores did not differ depending on whether being alone for a long time due to coronavirus. There are also studies in the literature that determine a negative directional relationship between loneliness and self-efficacy (Al Khatib, 2012; Lackaye \& Margalit, 2008; Mercan, Demirci, Ozler \& Oyur, 2015). In addition, Totan \& Kabasakal (2011) found that self-efficacy has mediating effects on the relationship between loneliness and hope. However, there are also studies in the literature reporting that loneliness and suicidal behavior are associated variables (Batıgün, 2008; Eskin, 2001; Page et al., 2006) but another study that examined the relationship between suicidal thoughts and loneliness found that $25 \%$ of people who consider suicide feel very lonely (Stravynski \& Boyer 2001). The fact that suicide probability and self-efficacy scores are not differentiated according to whether or not being alone due to coronavirus in the current study 
may be due to the fact that the coronavirus process is also perceived as a temporary process and the time spent in homes is seen as a means of rest, since other pandemics that previously affected the entire world could be prevented in some way.

According to another result of the study, it was found that those who said they were alone due to coronavirus had higher coronavirus anxiety scores than those who said they were not alone. Research has shown that long-term social isolation increases feelings of depression, anxiety and loneliness (Stickley \& Koyanagi, 2016; Reger et al., 2020; Wheaton et al., 2012). In a study conducted in Spain, it was found that $30 \%$ of the individuals staying at home in the early stages of the pandemic process had feelings such as loneliness, anger and anxiety (Orgilés et al., 2020). In this context, the current research result may be that individuals who develop anxiety about coronavirus, which contains both physical and mental threats, need a source of social support to survive this difficult process more healthily, which we do not know how long it will continue.

According to another result of the study, no differences were found in whether individuals were subjected to physical, emotional or sexual abuse during the coronavirus process and their self-efficacy scores. Studies have reported that individuals with emotional abuse have lower self-efficacy scores (Hussain \& Munaf, 2012). In addition, a study conducted by Kim \& Cicchetti (2003) found that adolescent individuals who were subjected to neglect and abuse had lower self-efficacy scores than those who were not exposed. However, it is stated that self- efficacy contributes to the individual's determination of how to manage these situations and regulate problem behaviors when faced with a negative life or risk situations (Caprara, Barbaranelli, Pastorelli \& Cervone, 2004; Telef \& Karaca, 2011).

The study found that the coronavirus anxiety scores of people who said yes to the question" Have you been subjected to physical, emotional or sexual abuse during your stay at home to protect against Coronavirus? " were higher than the coronavirus anxiety scores of people who said no. The fact that the pandemic process leads individuals to make difficult choices, trying to ensure home education conditions, the presence of older people in the household who need to be taken care of and be safe, and the raising of chronic emotional and behavioral problems can be effective in reaching this finding. As a matter of fact, Coyne et al. (2020) also notes that the pandemic process disrupts family relationships and causes household violence. A similar finding is that a study conducted in Australia showed a decrease in crime rates during the quarantine process created to provide protection against the pandemic, but an increase in domestic abuse cases. With the introduction of the quarantine process, domestic problems, domestic violence and abuse cases have been recorded in many countries as well as Australia (Usher \& Kim, 2020). An increase in the violence against women, the elderly, and 
children has been observed in the quarantine process in the United States, China, Brazil, \& Australia (Campbell, 2020). It was found that domestic violence in China tripled compared to last year, while in France, domestic abuse cases increased by 32-36\% (Allen, 2020; Li, 2020). As a result, research conducted in different countries shows an increase in family violence, physical, emotional and sexual abuse behaviors as a result of quarantine practices.

Another result from the study is that the suicide probability scores of people who said yes to the question "Have you been subjected to physical, emotional or sexual abuse during your stay at home to protect yourself from Coronavirus?" were higher than the suicide probability scores of people who said no. Quarantine, etc. measures taken by countries to deal with the pandemic on an individual and social scale can negatively affect the social support needs and social communication needs of individuals. In addition, due to the excessive responsibility associated with adapting to the pandemic process, individuals can experience negative processes such as post-traumatic stress disorder and depression due to the psychological effect of quarantine, and ongoing negative emotions can be replaced by an undesirable result such as suicide. In this context, when reviewing the literature, Brooks \& colleagues (2020) similarly expressed that individuals are moving away from their social support needs in quarantine processes, in later stages they need social support even more than usual. In addition, it is noted that when people looking for Social Support do not find the social support they need in their partner, child, relative and close social environment, their psychosocial adaptation will also be negatively affected (Mukhtar, 2020). Evaluating the coronavirus pandemic in terms of Health Services, Tang, Junjian \& Babatunde (2020) also states that the resources allocated as part of the emergency response to the outbreak may have prevented the transfer of resources to other health services (abortion, sexually transmitted diseases, post-traumatic stress disorder, depression, suicide, domestic violence). Based on this result, it can be concluded that coronavirus may play a role in increasing the likelihood of suicide in the context of social quarantine practices, which are a continuation of the anxiety caused by the pandemic, and the narrowing of resources allocated to the fight against coronavirus.

Finally, self-efficacy has been found to have a mediating role between coronavirus anxiety and the suicide probability. More specifically, the likelihood of suicide increases when coronavirus anxiety increases. But it has been determined that self-efficacy has a contribution that can partially reduce the suicide probability. Hocaoğlu \& Erdoğan (2020) also stated that negative emotional processes, such as anxiety, which are contained in the pandemic process, can have a negative impact on the mental health of individuals. In addition, fear of transmission caused by the pandemic process, anxiety, prolonged isolation and social stigma can lead to negative effects and make the possibility of suicide a risk factor. In the relevant literature, it has 
been reported that an increase was observed in psychiatric disorders during and after epidemics, as well as an increase in suicide attempts and suicide rates (Okusaga, Yolken, Langenberg, Lapidus, Arling \& Dickerson, 2020). It is thought that the coronavirus process, which affects the world, may increase the suicide probability. It is even predicted that this process could become a "suicide storm" (Brown \& Schuman, 2020). But it can be said that people who face similar risks will not face the same dangerous consequences. As a matter of fact, the use of functional struggle mechanisms and the resorting to social support resources is related to the high level of self-efficacy of individuals who experience compulsive emotions during the pandemic process. From this point of view, it can be assumed that individuals with a low perception of self-efficacy may increase the risk of taking steps towards ending their life instead of solving problems. Looking at the literature, Albal (2009) found that people without suicidal thoughts had higher levels of self-efficacy to cope with depression than people with suicidal thoughts. Weishaar (1996) associated the decline in self-ability levels with pessimistic thoughts and suicidal thoughts. In addition, a low level of self- efficacy weakens interpersonal relationships, causing the individual to consider himself inadequate for problem solving, and this process can leave the individual vulnerable to this risk as a hidden factor that can constitute suicide (Dieserud, Roysamb, Ekeberg \& Kraft, 2001). As a result, it is quite meaningful that selfefficacy plays a mediating role between coronavirus anxiety and the possibility of suicide. Because individuals with high levels of self- efficacy are sufficient to cope with various difficulties and this serves as a protective function for mental health (Çiçek \& Almall, 2020). But self-efficacy has a partial mediating effect on the relationship between coronavirus anxiety and suicide probability. In other words, it does not fully mediate. The concept of self-efficacy can be studied in two sub-factors (Arseven, 2016). These are the competency expectation and the outcome expectation. Competence expectation refers to the ability of people to cope with a challenging process. The outcome expectation tells us about being able to achieve success as a result of this struggle. People with high levels of self-efficacy may be trying to cope effectively with coronavirus anxiety and the difficulties caused by the pandemic. But there is some uncertainty about this difficulty. For example, it is unclear how long this process will take, or whether the ways to cope are effective. Therefore, people with high levels of self-efficacy have high expectations of competence, while the outcome expectation may be uncertain. This explains why self-efficacy has a partial effect on the relationship between coronavirus anxiety and the suicide probability.

According to research results, self-efficacy plays a mediating role between coronavirus anxiety and the suicide probability. In other words, even if people with a high level of selfefficacy experience coronavirus anxiety, they believe in themselves and use their skills to cope. This can reduce the likelihood of suicide. Another conclusion that can be drawn from the study is 
that women's self-efficacy levels are lower than men's, and coronavirus anxiety is higher. Again, coronavirus anxiety was found to be higher in those who said they were alone during the pandemic process than in those who were not alone. Finally, university students who were exposed to abuse during the pandemic were found to be more likely to have coronavirus anxiety and suicide probability than others.

In light of these results, a number of recommendations can be made to practitioners. First, it may be effective for the guidance and psychological counseling units of universities to carry out studies aimed at increasing self-efficacy. For example, psychoeducation programs, group counseling practices and skill training can be applied to increase the self-efficacy levels of university students. In addition, university students' coping mechanisms can be activated by slogans, banners, seminars and educational activities that emphasize self-efficacy in universities. In addition, policies aimed at strengthening social support systems in the pandemic process need to be implemented. "Social distance" has become the motto of this process. However, this motto refers directly to social relations itself. Instead, slogans such as "physical distance; social commitment" can be used to express both maintaining relationships and avoiding risks. Finally, home quarantines are being implemented to prevent the spread of coronavirus. Homes deemed safe to avoid the quarantine process may not be safe for everyone. As a matter of fact, in the current study, $9 \%$ of university students reported that they were subjected to physical, emotional or sexual abuse during the pandemic. In this process, having a hotline that people who are not in a safe home environment can contact by phone or online can be useful. 


\section{REFERENCES}

Akbay, S., \& Gizir, C. (2010). Cinsiyete göre üniversite öğrencilerinde akademik erteleme davranışı: akademik güdülenme, akademik özyeterlik ve akademik yükleme stillerinin rolü. [Academic procrastination among university students according to gender: the role of academic motivation, academic self-efficacy and academic attributional style] Mersin Üniversitesi Eğitim Fakültesi Dergisi, 6(1), 60-78.

Akkoyunlu, B., \& Orhan, F. (2003). Bilgisayar ve öğretim teknolojileri eğitimi (BÖTE) bölümü öğrencilerinin bilgisayar kullanma öz yeterlik inancı ile demografik özellikleri arasındaki ilişki. TOJET: The Turkish Online Journal of Educational Technology, 2(3).

Al Khatib, S.A. (2012). Exploring the relationship among loneliness, self-esteem, self-efficacy and gender in united arab emirates college students. Europe's Journal of Psychology, 8(1), 159-181. https://doi.org/10.5964/ejop.v8i1.301

Alabay, E. (2006). İlköğretim okulöncesi öğretmen adaylarının fen ile ilgili öz-yeterlik inanç düzeylerinin incelenmesi. Yeditepe Üniversitesi Ĕ̆itim Fakültesi Dergisi, 2, 1.

Albal, E. (2009). Depresyonla başa çıkmada öz yeterlik ile algılanan sosyal destek arasındaki iliş̧ki. [Master's thesis, İstanbul University, Health Sciences Institute: İstanbul]. Available from Yok Tez Merkezi database (247464).

Allen-Ebrahimian, B. (2020). China's Domestic Violence Epidemic, Axios.

Ammerman, B. A., Burke, T. A., Jacobucci, R., \& McClure, K. (2020). Preliminary investigation of the association between covid-19 and suicidal thoughts and behaviors in the US. https://doi.org/10.31234/osf.io/68djp

Arseven, A. (2016). Öz yeterlilik: bir kavram analizi. [Self-efficacy: a concept analysis]. Electronic Turkish Studies, 11(19). https://doi.org/10.7827/TurkishStudies.10001

Atay, İ. M., Eren, İ., \& Gündoğar, D. (2012). Isparta il merkezinde intihar girişimi, ölüm düşünceleri yaygınlığı ve risk faktörleri. [The Prevalence of Suicide Attempts, Death Ideas and the Risk Factors in the City of Isparta] Türk Psikiyatri Dergisi, 23(2), 89-98.

Atlı, Z., Eskin, M., \& Dereboy, Ç. (2009). İntihar Olasılı̆̆ı Ölçeğinin (İoÖ) klinik örneklemde geçerlik ve güvenirliği. [The Validity and the Reliliability of Suicide Probability Scale (SPS) in Clinical Sample] Klinik Psikiyatri Dergisi, 12(3), 111-124.

Aypay, A. (2010). Genel Öz yeterlik ölçeği'nin (GÖYÖ) Türkçe'ye uyarlama çalışması. [The Adaptation Study of General Self-Efficacy (GSE) Scale to Turkish] İnönü Üniversitesi Eğitim Fakültesi Dergisi, 11(2), 113-132.

Bandura, A. (1999). Self-efficacy pathways to childhood depression. Journal of Personality and Social Psychology, 76(2), 258-259.

Banerjee D. (2020). The COVID-19 outbreak: crucial role the psychiatrists can play. Asian Journal of Psychiatry. 50.

Batıgün, A. D. (2005). İntihar olasılığı: Yaşamı sürdürme nedenleri, umutsuzluk ve yalnızlık açısından bir inceleme. [Suicide Probability: An Assessment Terms of Reasons for Living, Hopelessness and Loneliness]. Türk Psikiyatri Dergisi, 16(1), 29-39.

Batıgün, D. A. (2008). İntihar olasılı̆̆ı ve cinsiyet: İletişim becerileri, yaşamı sürdürme nedenleri, yalnızlık ve umutsuzluk açısından bir inceleme. [Suicide Risk and Gender: An Evaluation of Suicide in Respect to Interpersonal Relationship Style, Reasons for Living, Loneliness, and Hopelessness] Türk Psikoloji Dergisi, 23(62), 65-75.

Berk, B. B. (2006). Macro-micro relationships in Durkheim's analysis of egoistic suicide. Sociological Theory,24(1), 58-80. https://doi.org/10.1111/j.0735-

2751.2006.00264.x 
Brooks, S. K., Webster, R. K., Smith, L. E., Woodland, L., Wessely, S., Greenberg, N., et al. (2020). The psychological impact of quarantine and how to reduce it: rapid review of the evidence. The Lancet. 395(10227):912-20.

Brown, S., \& Schuman, D. L. (2020). Suicide in the time of COVID-19: A perfect storm. J Rural Health. 3. https://doi.org/10.1111/jrh.12458

Campbell, A. M. (2020). An increasing risk of family violence during the Covid-19 pandemic: Strengthening community collaborations to save lives. Forensic Science International: Reports, 2, 100089.

Caprara, G. V., Barbaranelli, C., Pastorelli, C. \& Cervone, D. (2004). The contribution of selfefficacy beliefs to psychosocial outcomes in adolescence: Predicting beyond global dispositional tendencies. Personality and individual Differences, 37(4), 751-763. https://doi.org/10.1016/j.paid.2003.11.003

Cheyette, S. R., \& Cummings, J. L. (1995). Encephalitis lethargica: lessons for contemporary neuropsychiatry. The Journal of neuropsychiatry and clinical neurosciences, 7(2), 125.

Çiçek, B., \& Almalı, V. (2020). COVID-19 pandemisi sürecinde kaygı öz-yeterlilik ve psikolojik iyi oluş arasındaki ilişki: özel sektör ve kamu çalışanları karşılaştırması. [The Relationship Between Anxiety Self-efficacy and Psychological Well-Being during COVID-19 Pandemic Process: Comparison of Private and Public Sector Employees]. Turkish Studies, 15(4), 241-260.

Çölgeçen, Y., \& Çölgeçen, H. (2020). Covid-19 pandemisine bağlı yaşanan kaygı düzeylerinin değerlendirilmesi:türkiye örneği. [Evaluation of Anxiety Levels Arising From Covid-19 Pandemic: The Case of Turkey] Electronic Turkish Studies, 15(4). https://doi.org/10.7827/TurkishStudies.44399

Courtet, P., Olié, E., Debien, C., \& Vaiva, G. (2020). Keep socially (but not physically) connected and carry on: preventing suicide in the age of COVID-19. The Journal of clinical psychiatry, 81(3). https://doi.org/10.4088/JCP.20com13370

COVID-19 Pandemisinde Sağlık Kurumlarında Çalışma Rehberi ve Enfeksiyon Kontrol Önlemleri (Scientific Advisory Board Study) (2020). T.C. Ministry of Health, 24 July 2020.

Coyne, Lisa W., et al. (2020). First Things First: Parent Psychological Flexibility and SelfCompassion During COVID-19. Behavior Analysis in Practice, 1.

Craft, L. L. (2002). Exercise and Clinical Depression: Examining Psychological Mechanisms. Doctoral dissertation, Michigan State University, Michigan USA.

Cull J.G., \& Gill W.S. (1990) Suicide probability scale, Western Psychological Services, Los Angels.

Dieserud, G., Roysamb, E., Ekeberg, Q., \& Kraft, P. (2001). Toward an inte grative model of suicide attempt: A cognitive psychological approach. Suicide and Life-Threatening Behavior, 31(2), 155-160.

Dunmore R. (2020). Coronavirus-related suicides surface amid increased anxiety. Newsone.

Erdoğdu, Y., Koçoğlu, F., \& Sevim, C. (2020). COVID-19 pandemisi sürecinde anksiyete ile umutsuzluk düzeylerinin psikososyal ve demografik değişkenlere göre incelenmesi. [An investigation of the psychosocial and demographic determinants of anxiety and hopelessness during COVID-19 pandemic] Klinik Psikiyatri Dergisi, 23. https://doi.org/10.5505/kpd.2020.35403

Eskin, M. (2001). Ergenlikte yalnızlık, baş etme yöntemleri ve yalnızlığın intihar davranışı ile ilişkisi [Adolescent Loneliness, Coping Methods and the Relationship of Loneliness to Suicidal Behavior]. Klinik Psikyatri Dergisi, 4(1), 5-11. 
Evren, C., Evren, B., Dalbudak, E., Topcu, M., \& Kutlu, N. (2020). Measuring anxiety related to COVID-19: A Turkish validation study of the Coronavirus Anxiety Scale. Death Studies, 17.

Gilliam, C. M. (2005). The effects of rumination on problem-solving self-efficacy and self-efficacy for controlling upsetting thoughts in the context of depressive symptoms. Unpublished doctoral dissertation, University of Missouri, St. Louis.

Göksu, Ö. \& Kumcağız, H. (2020). COVID-19 salgınında bireylerde algılanan stres düzeyi ve kaygı düzeyleri. [Perceived Stress Level and Anxiety Levels in Individuals in Covid-19 Outbreak] Turkish $\quad$ Studies, 15(4): 463-479. https://doi.org/10.7827/TurkishStudies.44397

Harriss, L., Hawton, K., \& Zahl, D. (2005). Value of measuring suicidal intent in the assessment of people attending hospital following self-poisoning or self-injury. British Journal of Psychiatry, 186, 60-66. https://doi.org/10.1192/bjp.186.1.60

Hocaoğlu, Ç., \& Erdoğan, A. (2020). COVID-19 ve intihar. Coşar B, editör. Psikiyatri ve COVID-19. 1. Baskl. Ankara: Türkiye Klinikleri. p.35- 42.

Huang, Y., \& Zhao, N. (2020). Generalized anxiety disorder, depressive symptoms and sleep quality during COVID-19 outbreak in China: a webbased cross-sectional survey. Psychiatry Research.

Hussain, S., \& Munaf, S. (2012). Perceived Father Acceptance Rejection in Childhood and Psychological Adjustment in Adulthood. International Journal of Business and Social Science, 3,1.

Iob, E., Steptoe, A., \& Fancourt, D. (2020). Abuse, self-harm and suicidal ideation in the UK during the COVID-19 pandemic. The British Journal of Psychiatry,217(4), 543-546. https://doi.org/10.1192/bjp.2020.130

K. A., Witte, T. K., Cukrowicz, K. C., Braithwaite, S. R., Selby, E. A., \& Joiner Jr, T. E. (2010). The interpersonal theory of suicide. Psychological review, 117(2), 575.

Keskin, T. (2019). Sınıf Öğretmenlerinin Ĕgitsel Öz-Yeterlikleri ve Öğretmenlik Öz Yeterliklerinin Incelenmesi. [Master's thesis, Muğla Sıtkı Koçman University, Education Sciences Institute: Muğla]. Available from Yok Tez Merkezi database (601597).

Keskin, Ü. G., \& Orgun, F. (2006). Öğrencilerin öz etkililik-yeterlilik düzeyleri ile başa çıkma stratejilerinin incelenmesi. [Studying the strategies of students' coping with the levels of selfefficacy-sufficiency] Anadolu Psikiyatri Dergisi, 7, 93-97.

Kim, J., \& Cicchetti, D. (2003). Social Self-efficacy and behavior problems in maltreated and nonmaltre-ated children. Journal of Clinical Child and Adolescent Psychology, 32(1), 106117. https://doi.org/10.1207\%2FS15374424JCCP3201_10

Kjoller, M., \& Helweg-Larsen, M. (2000). Suicidal ideation and suicide attempts among adult Danes. Scandinavian Jornal of Public Health, 28, 54-61. Https://doi.org/10.1177/140349480002800110

Kul, A., Demir, R., \& Katmer, A. N. (2020). Covid-19 salgını döneminde psikolojik sağlamlığın yordayıcısı olarak yaşam anlamı ve kaygı. [Meaning of life and anxiety as predictors of psycholological resilience during the covid-19 epidemic] Electronic Turkish Studies, 15(6). 695-719. https://doi.org/10.7827/TurkishStudies.44419

Kumar, C. T. S., Mohan, R., Ranjith, G., \& Chandrasekaran, R. (2006). Gender differences in medically serious suicide attempts: A study from South India. Psychiatry Research, 144, 79-86. https://doi.org/10.1016/j.psychres.2005.11.012

Lackaye, T., \& Margalit, M. (2008). Self-efficacy, loneliness, effort, and hope: developmental differences in the experiences of students with learning disabilities and their non- 
learning disabled peers at two age groups. learning disabilities: A Contemporary Journal, 6(2), 1-20. https://doi.org/10.1111/j.1540-5826.2006.00211.x

Lai J, Ma S, Wang Y, et al. (2020). Factors associated with mental health outcomes among health care workers exposed to Coronavirus Disease 2019. JAMA Network Open, 3(3). https://doi.org/10.1001/jamanetworkopen. 2020.3976

Lee, S. A. (2020). Coronavirus Anxiety Scale: A Brief Mental Health Screener for COVID-19 related anxiety. Death Studies, 44(7), 393-401. https://doi.org/10.1080/07481187.2020.1748481

Lee, S. A., Jobe, M. C., Mathis, A. A., \& Gibbons, J. A. (2020). Incremental validity of coronaphobia: Coronavirus anxiety explains depression, generalized anxiety, and death anxiety. Journal of Anxiety Disorders, 74, 102268.

Li, S., Wang, Y., Xue, J., Zhao, N., \& Zhu, T. (2020). The impact of COVID-19 epidemic declaration on psychological consequences: a study on active Weibo users. International journal of environmental research and public health, 17(6), 2032.

Liu, S., You, J., Ying, J., Li, X., \& Shi, Q. (2020). Emotion reactivity, nonsuicidal self-injury, and regulatory emotional self-efficacy: a moderated mediation model of suicide ideation. Journal of Affective Disorders, 266, 82-89.

Mak, I. W., Chu, C. M., Pan, P. C., Yiu, M. G. \& Chan, V. L. (2009). Long-term psychiatric morbidities among SARS survivors. Gen Hosp Psychiatry. 31(4), 318-26.

Mann, J. J., Apter, A., Bertolote, J., Beautrais, A., Currier, D., Haas, A., ... \& Mehlum, L. (2005). Suicide prevention strategies: a systematic review. Jama, 294(16), 2064-2074. https://doi.org/0.1001/jama.294.16.2064

Mercan, N., Demirci, K., Ozler, D., \& Oyur, E. (2015). İş yaşamında yalnızlık, duygusal zeka ve psikolojik sermaye arasındaki ilişkiler üzerine bir araştırma. [A study on the relations between loneliness, emotional intelligence and psychological capital] MANAS Sosyal Araştırmalar Dergisi, 4(5), 197-211.

Mercer, K. L. (2004). Relations of Self-Efficacy to Symptoms of Depression and Anxiety in Adolescents with Learning Disabilties [Unpublished doctoral dissertation]. University of British Colombia.

Mertler, C. A., \& Vannatta, R. A. (2005). Advanced and multivariate statistical methods: Practical application and interpretation (third edition). Pyrczak Publishing.

Molina, J. A., \& Duarte, R. (2006). Risk determinants of suicide attempts among adolescents. American Journal of Economics and Sociology, 65(2), 407-434. https://doi.org/10.1111/j.1536-7150.2006.00456.x

Mukhtar, M. S. (2020). Mental health and psychosocial aspects of coronavirus outbreak in Pakistan: psychological intervention for public mental health crisis. Asian Journal of Psychiatry.

Okusaga, O., Yolken, R. H., Langenberg, P., Lapidus, M., Arling, T. A., Dickerson, F. B., ... \& Postolache, T. T. (2011). Association of seropositivity for influenza and coronaviruses with history of mood disorders and suicide attempts. Journal of Affective Disorders, 130(1-2), 220-225.

Orgilés, M., Morales, A., Delvecchio, E., Francisco, R., Mazzeschi, C., Pedro, M., ve Espada, J. P. (2020). Coping behaviors and psychological disturbances in youth affected by the COVID-19 health crisis. https://doi.org/10.31234/osf.io/2gnxb

Oyesanya, M., Lopez-Morinigo, J., \& Dutta, R. (2015). Systematic review of suicide in economic recession. World Journal of Psychiatry, 5(2), 243. https://doi.org/10.5498/wjp.v5.i2.243 
Page, R. M., Yanagishita, J., Suwanteerangkul, J., Zarco, E.P., Mei-Lee, C. \& Miao, N. F. (2006). Hopelessness and loneliness among suicide attempters in school-based samples of Taiwanese, Philippine and Thai Adolescents. School Psychology International, 27, 583598.

Preacher, K. J. \& Hayes, A. F. (2004). SPSS and SAS procedures for estimating indirect effects in simple mediation models. Behavior Research Methods, Instruments, \& Computers, 36(4), 717-731.

Preacher, K. J. \& Hayes, A. F. (2008). Asymptotic and resampling strategies for assessing and comparing indirect effects in multiple mediator models. Behavior Research Methods, 40(3), 879-891.

Reger, M. A, Stanley, I. H., \& Joiner, T, E. (2020). Suicide mortality and coronavirus disease 2019a perfect storm? JAMA Psychiatry. https://doi.org/10.1001/jamapsychiatry.2020.1060

Şahin, N. H., \& Batıgün, A. D. (2009). Lise ve üniversite öğrencilerinde intihar riskini belirlemeye yönelik bir modelin sınanması. Türk Psikiyatri Dergisi, 20(1), 28-36.

Sahoo, S., Bharadwaj, S., Parveen, S., Singh, A. P., Tandup, C., Mehra, A., ... \& Grover, S. (2020). Selfharm and COVID-19 Pandemic: An emerging concern-A report of 2 cases from India. Asian journal of psychiatry. https://doi.org/10.1016/j.ajp.2020.102104

Schwarzer, R., \& Jerusalem, M. (1995). Generalized self-efficacy scale. Measures in health psychology: A user's portfolio. Causal and control beliefs, 1(1), 35-37.

Selvi, G. (2020). Sınıf öğretmenlerinin etkileşimli tahta kullanımına yönelik öz-yeterlik algı düzeylerinin belirlenmesi: Fatih Projesi örneği [Unpublished master's thesis].Sakarya University.

Sher, L. (2020). The impact of the COVID-19 pandemic on suicide rates. QJM: An International Journal of Medicine, 113(10), 707-712. https://doi.org/10.1093/qjmed/hcaa202

Stickley, A., \& Koyanagi, A. (2016) Loneliness, Common Mental Disorders and Suicidal Behavior: Findings from a General Population Survey. Journal of Affective Disorders, 197, 81-87. Https://doi.org/10.1016/j.jad.2016.02.054

Stravynski, A., \& Boyer, R. (2001). Loneliness in relation to suicide ideation and parasuicide: A population-wide study. Suicide and Life-Threatening Behavior, 31(1), 32-40. Https://doi.org/10.1521/suli.31.1.32.21312

T.C. Sağlık Bakanlığı, Halk Sağlığı Genel Müdürlüğü, COVID-19 (2019-n CoV Hastalığı) Rehberi (Bilim Kurulu Çalışması) (2020). T.C. Sağlık Bakanlığı, 14 Nisan 2020.

Tabachnick, B. G., \& Fidell, L. S. (2013). Using multivariate statistics (Sixth edition).Pearson Education.

Tang, K., Gaoshan, J., Ahonsi, B., Ali, M., Bonet, M., Broutet, N., ... \& Thwin, S. S. (2020). Sexual and reproductive health (SRH): a key issue in the emergency response to the coronavirus disease (COVID-19) outbreak. Reproductive Health, 17, 1-3.

Tate, C. M. (2005). Revision of the self-efficacy questionnaire of social skills for use with deaf college students [Unpublished doctoral dissertation]. Gallaudet University.

Taylor, D., \& Bury, M. (2007). Chronic illness, expert patients and care transition. Sociology of Health \& Illness, 29(1), 37-39.

Telef, B. B., \& Karaca, R. (2011). Ergenlerin öz-yeterliklerinin ve psikolojik semptomlarının incelenmesi. [Adolescents' self-efficacy and psychological symptoms' investigation] Mustafa Kemal Üniversitesi Sosyal Bilimler Enstitüsü Dergisi, 8(16), 499-518.

Thomas, H. V., Crawford, M., Meltzer, H. \& Lewis, G. (2002). Thinking life is not worth living. Social Psychiatry and Psychiatric Epidemiology, 37, 351-356. https://doi.org/10.1007/s00127-002-0556-5 
Totan, T., \& Kabasakal, Z. (2011). İlköğretim öğrencilerinde yalnızlık ve umut arasındaki ilişkilerde öz-yeterlik alanlarının aracılık etkileri, 20.Ulusal Eğitim Bilimleri Kurultayı. Konya.

Tull, M. T., Edmonds, K. A., Scamaldo, K., Richmond, J. R., Rose, J. P., \& Gratz, K. L. (2020). Psychological outcomes associated with stay-at-home orders and the perceived impact of covid-19 on daily Research, 289. https://doi.org/10.1016/j.psychres.2020.113098

Usher, K., Bhullar, N., Durkin, J., Gyamfi, N., \& Jackson, D. (2020). Family violence and COVID-19: Increased vulnerability and reduced options for support. International Journal of Mental Health Nursing (2020) 29, 549-552. https://doi.org/10.1111/inm.12735

Weishaar, M. E. (1996). Cognitive Risk Factors in Suicid. İçinde: P. M. Salkovskis (Ed). Frontiers of Cognitive Therapy. Guilford Press.

Wheaton, M. G., Deacon, B. J., McGrath, P. B., Berman, N. C., \& Abramowitz, J. S. (2012). Dimensions of anxiety sensitivity in the anxiety disorders: Evaluation of the ASI-3. Journal of Anxiety disorders, 26(3), 401-408. https://doi.org/10.1016/j.janxdis.2012.01.002

Whetstone, L. M., Morrissey, S. L., \& Cummings, D. M. (2007). Children at risk: The association between perceived weight status and suicidal thoughts and attempts in middle school youth. Journal of School Health, 77(2), 59-66. https://doi.org/10.1111/j.1746-Bu 1561.2007.00168.x

WHO (2020). WHO characterizes COVID-19 as a pandemic. https://www.who.int/emergencies/diseases/novel-coronavirus-2019/events-as-theyhappen (Date of Access: 01 January 2020).

Yates, T. M. (2007). The developmental consequences of child emotional maltreatment: A neurodevelopmental perspective. Journal of Emotional Maltreatment, 7(2), 9-34. https://doi.org/10.1300/J135v07n02_02

Zhang, Y., Xiao, M., Zhang, S., Xia, P., Cao, W., Jiang, W., ... \& Wang, C. (2020). Coagulopathy and antiphospholipid antibodies in patients with Covid-19. New England Journal of Medicine, 382(17), e38. https://doi.org/10.1056/NEJMc2007575 


\section{GENIŞLETİLMİ̧ ÖZET}

\section{Giriş}

Koronavirüs 31 Aralık 2019'da Çin'de ortaya çıkmış ve bütün dünyayı etkisi altına almıştır. Koronavirüsün dünya çapında yaygınlaşması sonucunda bu DSÖ bu durumu pandemi olarak ilan etmiştir. İnsanlar koronavirüsün olumsuz etkilerinden korunmak için sosyal mesafe kurallarına uymaya çalışmış ve uzun süreli ev karantinalarında kalmıştır. Koronavirüs insanları fiziksel olarak etkilediği gibi psikolojik olarak da olumsuz sonuçlara yol açmıştır. Nitekim pandemi süreçlerinin ruh sağlığına yönelik olumsuz etkileri daha önceki araştırmalara da konu olmuştur. Depresyon, kaygı, uyku bozuklukları, mani, obsesif kompülsif bozukluk (OKB), travma sonrası stres bozukluğu (TSSB), panik bozukluk, yaygın anksiyete bozukluğu ve hiperaktivitenin pandemiler sırası ve sonrası en çok karşılaşılan psikiyatrik bozukluklar olduğu ifade edilmektedir (Cheyette ve Cummings, 1995; Huang ve Zhao, 2020; Mak, Chu, Pan, Yiu ve Chan, 2009). Öngörülemeyen sonuçlar, belirsizlikler, sosyal izolasyon ve karantina gibi kısıtlayıcı uygulamalar bireylerde kaygı, üzüntü, korku, panik, kızgınlık, öfke, hayal kırıklığı, suçluluk, umutsuzluk ve yalnızlığa neden olmaktadır (Sher, 2020). Karantina sürecinin uzaması, bireyin kendisinin veya aile fertlerinden birinin hastalığa yakalanma kaygısı, süreçte rol alan yetkililerden aktüel bilgi alınamaması ve tıbbi bakımda karşılaşılan yetersizlikler bireylerdeki olumsuz psikolojik etkiyi arttırmaktadır (Courtet ve diğerleri, 2020; Ammerman ve diğerleri, 2020). Pandemi sürecinde karşılaşılması muhtemel olan önemli psikososyal sorunlardan biri de intihardır. Mann ve diğerleri (2005) yaptıkları araştırmada psikotik ve madde kullanım bozuklukları gibi önceden var olan psikiyatrik rahatsızlıkları olan bireylerin yüksek intihar riski altında olduğunu vurgulamıştır. Pandemi sürecinde kadınlar, azınlık gruplar, sosyoekonomik dezavantaj, işsizlik, engellilik ve kronik fiziksel veya psikolojik hastalığa sahip bireylerin intihar riskinin daha yüksek olduğu saptanmıştır (Iob, Steptoe ve Fancourt, 2020). Bununla beraber iş kaybı ve ekonomik kriz intihar için iyi bilinen diğer risk faktörlerindendir (Huang ve Zhao, 2020). Tarihsel olarak ekonomik krizlerin yüksek intihar oranları ile ilişkili olduğu bildirilmiştir (Tull ve diğerleri, 2020; Oyesanya, Lopez-Morinigo ve Dutta; 2015). Bu bağlamda pandemiye bağlı gelişen işsizlik, ekonomik kriz gelecekte daha yüksek intihar oranları ile ilişkili olabileceği üzerinde durulmaktadır (Van ve diğerleri, 2010). Dolayısıyla pandemi sürecin psikolojik güçlüklerin yanı sıra sosyal değişimler de insanları olumsuz etkilemektedir. Durkheim, egoistik intiharın bir bireyin belirli bir gruba yeterince dahil olamadığı, diğer bir deyişle sınırlı sayıda sosyal bağ olduğu zaman meydana geldiğini vurgulamıştır (Berk, 2006). Sosyal bağın güçlü olmasının intiharın önlenmesinde kilit rol oynadığı önde gelen intihar kuramlarında da belirtilmiştir (Huang ve Zhao, 2020). Bireyin sosyal bağının güçlü olması ve aidiyet hissetmesi, kendisine ve çevresine karşı sorumluluklarını yerine getirme konusunda daha çok çaba sarf 
etmesini ve öz yeterliliğin yükselmesini de beraberinde getireceği söylenebilir. Öz yeterlilik bireyin bir eylemi yapabilmek için gerekli yeteneğe sahip olmasına, eylemi yapabileceğine dair geliştirdiği motivasyon ve inanç olarak tanımlanmaktadır (Bandura,1999). Alabay (2006)'a göre öz yeterlilik, bireylerin başlarından geçen olumsuz olayları başarılı bir şekilde atlatabilmelerine yönelik kendilerine inanmaları anlamına gelmektedir. Sonuç olarak koronavirüs pandemisi sürecinde ruh sağlığı açısında risk faktörleri artmış durumdadır. Salgın sürecinde ortaya çıkan risk faktörleriyle birlikte bir ruh sağlığı sorunu olan intihar olgusunun da artabileceği ön görülmektedir (Brown ve Schuman, 2020). Fakat karşılașllan krizlerle sağlıklı şekilde baş etmeye yardım edecek bir yapı olarak görülen öz yeterlilik inancının intihar olasılı̆̆ını azaltabileceği düşünülmektedir. Buradan hareketle bu araştırmada Koronavirüs kaygısıyla intihar olasılığı arasındaki ilișkide öz yeterliliğin aracı rolü ele incelemek amaçlanmaktadır.

\section{Yöntem}

$\mathrm{Bu}$ araștırmanın amacı koronavirüs anksiyetesiyle intihar olasılıkları arasındaki ilișkide öz yeterliliğin aracı rolünü tespit etmektir. Araştırmaya toplam 341 (247 Kadın, 94 Erkek) üniversite öğrencisi katılım göstermiștir. Araştırmada katılımcılarından veri toplamak amacıyla İntihar Olasıllğı Ölçeği, Koronavirüs Anksiyetesi Ölçeği ve Genel Öz Yeterlilik Ölçeği kullanılmıştır. Bu araştırmada üniversite öğrencilerinin koronavirüs anksiyetesi ile intihar olasılığı arasındaki ilişkisinde öz yeterliliğin aracı rolünün incelenmesi amaçlanmıştır. Araştırma betimsel türde ilişkisel tarama modeliyle gerçekleştirilmiştir. Araştırmada koronavirüs anksiyetesi bağımsız değișken, öz yeterlilik aracı değișken ve intihar olasılığı bağımlı değișken olarak işlem görmektedir. Koronavirüs anksiyetesi ve öz yeterliliğin intihar olasılığı üzerindeki yordayıcı rolünün tespit edilmesi amacıyla hiyerarşik regresyon analizi kullanılmıştır. Aynı zamanda yeterliliğin koronavirüs anksiyetesi ve intihar olasılı̆̆ı arasındaki aracı rolünün incelemek için 10.000 tekrarlı örnekleme yönteminden (bootstrapping) faydalanılmıștır. Bu analiz için SPPS-macro programı (Preacher ve Hayes, 2004; 2008) kullanılmıștır.

\section{Bulgular}

Araștırma sonuçlarına göre öz yeterliliğin koronavirüs anksiyetesi ve intihar olasılı̆̆ı arasındaki ilişkide kısmi olarak aracı rol oynadığı bulunmuştur. Buna göre öz yeterliliğin artmasıyla intihar olasılığının azaldığı belirlenmiştir. Aynı zamanda koronavirüs sebebiyle yalnız kaldığını söyleyenlerin koronavirüs kaygısı puanlarının yalnız kalmadığını söyleyenlere göre daha yüksek olduğu bulunmuştur. Son olarak pandemi sürecinde, pandemi şartlarından dolayı istismara uğrayanların koronavirüs kaygısı ve intihar olasılıkları puanlarının istismara uğramayanlara göre daha yüksek olduğu belirlenmiștir. 


\section{Tartışma ve Sonuç}

Araştırmada öz yeterliliğin, koronavirüs ansiyetesi ile intihar olasıllı̆ı arasında kısmı aracılık ettiği bulunmuştur. Daha açık bir ifadeyle koronavirüs anksiyetesi arttığında intihar olasılığı artmaktadır veöz yeterliliğin intihar olasılığını kısmi olarak azaltabilecek bir katkısının olduğu belirlenmiştir. Hocaoğlu ve Erdoğan (2020) da pandemi sürecinin içinde barındırmış olduğu kaygı vb. olumsuz duygusal süreçlerin bireylerin ruh sağlığı üzerinde olumsuz etkilerinin olabileceğini ifade etmiştir. Ek olarak salgın sürecinin meydana getirdiği bulaş korkusu, kaygl, uzun süre sosyal izolasyonda kalmak ve sosyal açıdan damgalanmanın olumsuz etkileri beraberinde getirerek intihar olasılığını risk faktörü haline getirebilir. İlgili alan yazında salgınlar sırasında ve sonrasında psikiyatrik bozuklukların artması ile intihar girişimi ve intihar oranlarında da artışın meydana geldiği bildirilmiştir. (Okusaga, Yolken, Langenberg, Lapidus, Arling ve Dickerson, 2020). Dünyayı etkisi altına alan koronavirüs sürecinin intihar olasılığını arttırabileceği düşünülmektedir. Hatta bu sürecin "intihar fırtınası" haline gelebileceği ön görülmektedir (Brown ve Schuman, 2020). Fakat benzer risklerle karşılaşan insanların aynı tehlikeli sonuçlarla karşılamayacağı söylenebilir. Nitekim pandemi sürecinde zorlayıcı duygular yaşayan bireylerin işlevsel başa çıkma mekanizmaları kullanması ve ihtiyaç duyduklarında sosyal destek kaynaklarına başvurmaları bu kişilerin yüksek öz yeterlilik düzeyiyle ilgilidir. Bu açıdan değerlendirildiğinde düşük öz yeterlilik algısı olan bireylerin sorunları çözmek değil, hayatını sonlandırma yönünde adımlar atma riskini artırabileceği düşünülebilir. Literatür incelendiğinde Albal (2009) yaptığı araştırmada intihar düşüncesi olmayan bireylerin, intihar düşüncesi olan bireylere göre depresyonla başa çıkma yönünde öz yeterlilik düzeylerinin daha yüksek olduğu bulunmuștur. Weishaar (1996)'da öz yeterlilik düzeyinin düşük olmasını, kötümser düşünceler ve intihar düşünceleri ile ilişkilendirmiştir. Ek olarak öz yeterlilik seviyesinin düşük olması kişilerarası ilişkileri zayıflatarak bireyin kendisini problem çözme konusunda yetersiz görmesine neden olur ve bu sürecin intiharı oluşturabilecek gizli bir faktör olarak bireyi bu riske karşı savunmasız bırakabileceği ifade edilebilir (Dieserud, Roysamb, Ekeberg ve Kraft, 2001). Sonuç olarak öz yeterliliğin koronavirüsü anksiyetesi ile intihar olasıllı̆ı arasında aracı bir rolünün olması oldukça anlamlıdır. Çünkü öz yeterlilik düzeyi yüksek bireyler çeşitli zorluklarla baş etme konusunda yeterli olduğundan bu durum ruh sağlığını koruyucu bir işlev görmektedir (Çiçek ve Almalı, 2020). Ancak öz yeterlilik, koronavirüs anksiyetesi ile intihar olasılığı arasındaki ilişkiye kısmi olarak aracılık etmektedir. Başka bir deyişle tam aracılık etmemektedir. Öz yeterlilik kavramının iki alt faktörde incelenebilir (Arseven, 2016). Bunlar yetkinlik beklentisi ve sonuç beklentisidir. Yetkinlik beklentisi, insanların zorlu bir süreçle baş edebilmelerini ifade eder. Sonuç beklentisi ise bu mücadele sonucunda bir başarı elde edebilmeyi anlatır. Öz yeterlilik düzeyi yüksek insanlar koronavirüs anksiyetesiyle ve pandeminin getirdiği güçlüklerle etkili şekilde baş etmeye çalışıyor olabilir. Fakat yaşanan bu 
güçlük hakkında bazı belirsizlikler bulunmaktadır. Örneğin bu sürecin ne kadar süreceği ya da baş etme yollarının gerecekten etkili olup olmadığı belirsizdir. Dolayısıyla öz yeterlilik düzeyi yüksek insanların yetkinlik beklentisi yüksekken sonuç beklentisi belirsiz olabilir. Bu durumun öz yeterliliğin, koronavirüs ansiyetesi ile intihar olasılığı arasındaki ilişkide kısmi araçlık ettiğini açlklar niteliktedir. 